\title{
Toxic Gaslighting: On the Ins and Outs of Pollution
}

\author{
LIZA GRANDIA \\ UNIVERSITY OF CALIFORNIA, DAVIS
}

\begin{abstract}
Outdoor images predominate in cultural conceptions of "air pollution," whilst indoor air quality (IAQ) is typically tenfold more contaminated. Recent nonprofit research revealed that "green label" carpet contains up to 44 hazardous substances. How and why do school administrators not know this? When people speak colloquially about "toxic" schools, they typically refer to social environments whose power dynamics are manipulated by difficult people (bullies, narcissists, gaslighters, etc.). In this article, I borrow the cultural concept of gaslighting to query how and why the literal off-gassing of banal objects like carpet have escaped scientific inquiry. In dialogue with recent innovative air studies in California that blur the boundaries of in/outdoor pollution, this auto-ethnographic paper chronicles a carpet controversy at "Beacon" Elementary, a bilingual school in the Central Valley. Even as outdoor smoke from California wildfires in 2017 pushed $\mathrm{PM}_{25}$ levels past red into unprecedented magenta alerts, children were sickened inside school classrooms after new carpets were laid in 2017. By "outing" internal school board communication through repeated public records requests, Beacon mothers discovered how a chemical risk manager on the board manipulated confusion about patterns of pollution to dismiss the mothers' citizen science of the chemical abuse of their children. When pollution occurs outof-sight (in locked classrooms) or affects groups rarely studied in exposure (minors), institutions can easily deploy gaslighting techniques of doubt, denial, and disavowal of the chemical abuse of children. Given the slow (Nixon 2011), delayed, incremental, and "gaslighted" nature of modern chemical violence, even those harmed by chronic pollution may misrecognize the symptoms; those that do recognize the symptoms may be perceived or portrayed as delusional in stories worthy of Hollywood noir.
\end{abstract}

\section{Keywords}

carpet; air pollution; indoor air quality; citizen science; environmental justice

Liza Grandia, Email: lgrandia@ucdavis.edu 


\author{
"So when life is getting scary, be your own illuminary." \\ -Lin-Manuel Miranda, composer and lead leerie, Mary Poppins II \\ "And O! before you hurry by with ladder and with light, O Leerie, \\ see a little child and nod to him tonight!" \\ -Robert Louis Stevenson, "The Lamplighter"
}

\title{
Introduction
}

"Green label" carpet contains at least 44 hazardous substances. How and why do school administrators, much less the general public, not know this? As a subject of normalized risk, synthetic carpet is captivating because most people in the US now spend their lives indoors surrounded by it. More than half of indoor flooring in the US is carpet and Americans lay enough new carpet each year to cover $40 \%$ of Rhode Island. While early industrial rugs wove together natural ingredients, a carpet factory in Dalton, Georgia stumbled upon a new technique in 1947 for using a styrene-butadiene latex to adhere synthetic fibers onto a vinyl backing. Called "tufted carpet," it became cheap enough to be laid wall-to-wall. Sales skyrocketed fiftyfold in a decade. By the mid-1970s, 95\% of all US carpet production was synthetic (Berry and Rondinelli 2000).

Home tastes change, however. By the period of late industrialism (defined by Fortun as late-1980s), sales began to stagnate (Berry and Rondinelli 2000). Through its trade association (the Carpet and Rug Institute, CRI), the multi-billion-dollar carpet industry began aggressively advertising to hospital administrators and school facilities managers with a series of "fact sheets" to override commonsense concerns about germs and allergens. Within a generation, carpet spread to places previously considered unhygienic: restaurants, daycare facilities, elementary schools, even premier cancer hospitals. Transcending the threshold between the indoors/outdoors, carpet surrounds children's lives-from their bedrooms to their classrooms to their stadiums to the interiors of recreational vehicles that transport them to and fro. In droughtprone California, turf is also enjoying an outdoor resurgence as a supposed "eco" alternative to water-intensive lawns. To enjoy a carpet aesthetic after death, some even put astroturf on gravesites.

All-American, ubiquitous, soft, silent...but is it safe? After a fifth of the US Environmental Protection Agency's own staff were sickened by carpet in the late 1980s, the carpet industry responded by creating its own privately-certified "green" label in 1991. As reports of carpet-related illnesses continued across the country, Congressional representatives Bernie Sanders and Joe Lieberman commissioned laboratory tests of these "green" labeled carpets. In shocking footage on the CBS evening news, exposure to these supposedly "eco" carpets paralyzed and killed laboratory mice. CRI president Ron VanGelderan responded with classic corporate disavowal, "We have no evidence that exposure to carpet will cause any ill health effects. If it happens to mice, it does not necessarily mean that it's going to happen to human beings. That relationship has not been established. All of the tests . . we are convinced 
that it is not carpet as it is being manufactured [killing the mice]." He continues to externalize the blame, saying, "There is something that happens somewhere out in the field, and we've got to identify that" (Rather 1992, emphasis mine).

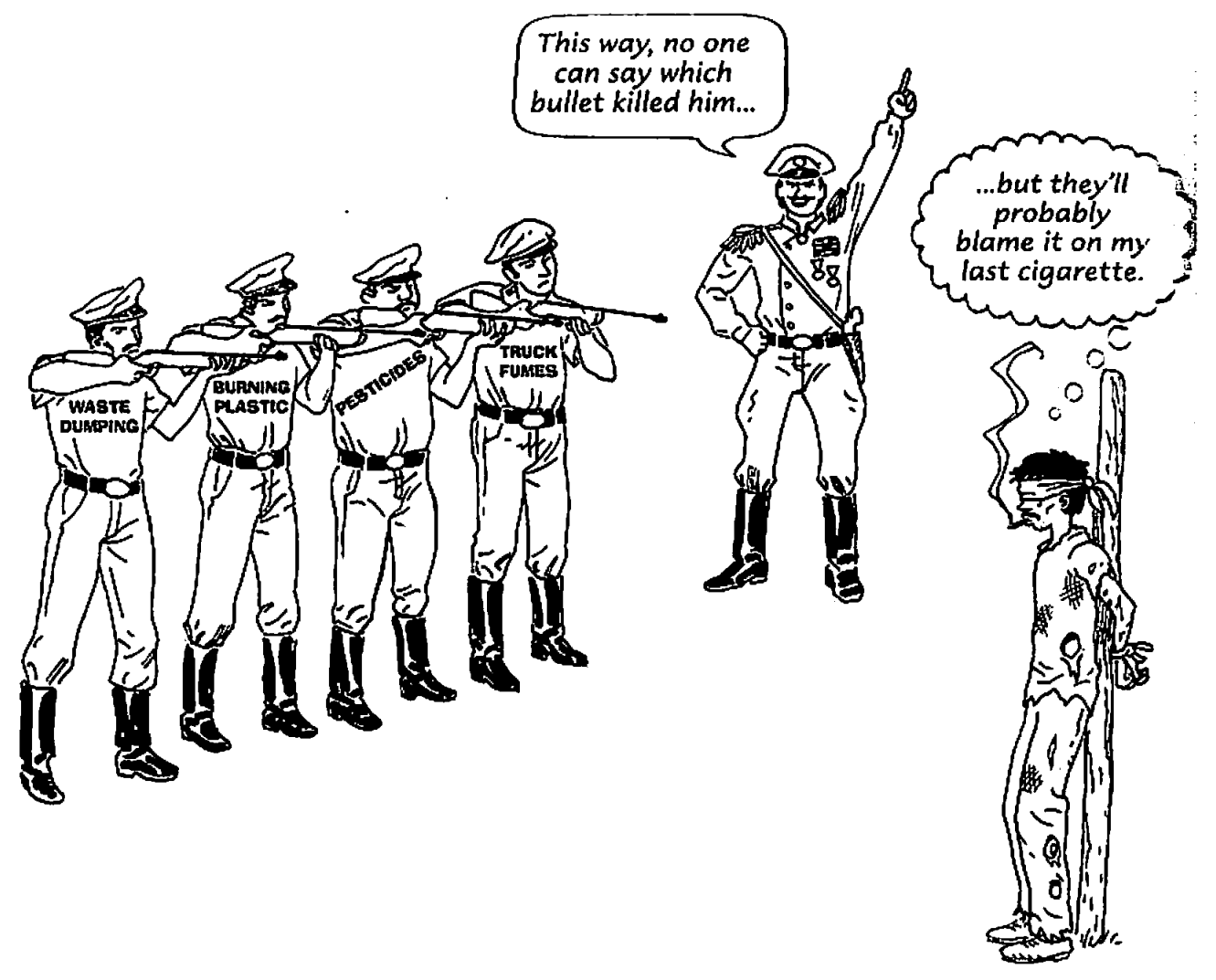

Figure 1: Firing Squad, Hesperian Foundation

Like other chemical executives, he knows that humanity is so awash in synthetic chemicals that it becomes virtually impossible to prove causality of any one product, as the macabre cartoon above illustrates (Conant and Faden 2008). With limited liability, the corporation as a legal person (stitched together Frankensteinian style from a long series of court cases) exhibits a number of narcissistic if not downright psychopathological tendencies: disregard for the safety of others, deceit, absence of remorse, selfishness, aggression, narrow economic selfinterest focused on shareholder profits, absolute denial of wrongdoing, and other classic gaslighting techniques to cover their tracks and avoid liability for environmental harm (Babiak and Hare 2006). Above all, corporations have honed the legal tricks of externalizing blame-a smoke and mirrors game of deceit, denial, and doubt (Michaels 2008). Like gaslighters, through 
the ploy of "public relations" and greenwashed labels, they deliberately dim the illumination of attention away from their environmental crimes and cast their critics as crazed (Stauber and Rampton 1995). Corporate spin strategies are so commonplace that they have been internalized and absorbed by governmental entities themselves, even local school boards.

Because so much of indoor-air science remains undone (Fricke et al. 2010; Allen and Macomber 2020), even those looking for causes of late-industrial illness seem to be measuring in the wrong places. Blinded by binary ontologies (Fortun 2014):

- In air quality research, outdoor pollution $>$ indoor pollution.

- In health problems, acute > chronic or developmental harm.

- In planetary disasters, climate/energy $>$ toxicity.

The academic literature on the anthropocene overwhelmingly focuses on al fresco topics associated with climate change: natural weather disasters, food security issues, and the spread of zoonotic diseases and far less on interior questions of toxicity. Like Boudia (2018), I am interested in disrupting the "outdoorsy" narrative of the anthropocene by drawing attention to the irreversible residue in bodies, especially those of children, from banal objects like carpet. As I will show, when pollution occurs out-of-sight (in locked classrooms) or affects groups rarely studied in exposure (minors), institutions can easily deploy techniques of doubt, denial, and disavowal of the chemical abuse of children.

Sunny California is an iconic place for rethinking the hazy in/outdoor boundaries of lateindustrial pollution. Once territory to a quarter of the original peoples of North America, California has become an occupied settler land of homogenous office complexes and suburban tract housing-all cheaply made and falling into disrepair. From red-carpet Hollywood to dot.com cubicles, new carpet is a symbol of luxury, excess, wealth, and refurbishment. A place of constant change, renewal, and renovation, California now represents an astounding third of carpet sales in the US. Although carpet is synthesized entirely from petroleum-derivatives and coal by-products, as a polluting object, it had escaped regulatory scrutiny until California nonprofit coalitions released a series of shocking reports in 2017-19 about the toxicity of "green label" carpet. These coincided with a new carpet crisis at "Beacon" Elementary, a bilingual MexicanAmerican school in the Central Valley. Despite evidence that a dozen children were ill, the school board ignored - or perhaps deliberately gaslighted - the problem for two years.

In this auto-ethnographic account of the mothers' grassroots struggle to seek remedy for this indoor air crisis, I make sociological use of the psychological concept of gaslighting (drawn from a 1944 Bergman film) to understand how/why the worried words of the Beacon mothers were both literally and paradigmatically muffled in the school board's own carpeted meeting room. Through this "conceptual haze" (Fortun 2014), a chemical risk manager who occupied a seat on the school board of trustees easily manipulated confusion about indoor/outdoor patterns of pollution to dismiss mothers' citizen science and deflect liability. Although environmental health scientists agree that children are uniquely and disproportionately affected by pollution, we have remarkably few studies about how children experience toxicity (Rudestam et al. 2004), 
especially in indoor settings in which they spend nine-tenths of their lives (Allen and Macomber 2020). When exposures occur round-the-clock and from cradle-to-grave, how can someone pinpoint a ubiquitous object like carpet as a lingering cause of ill health?

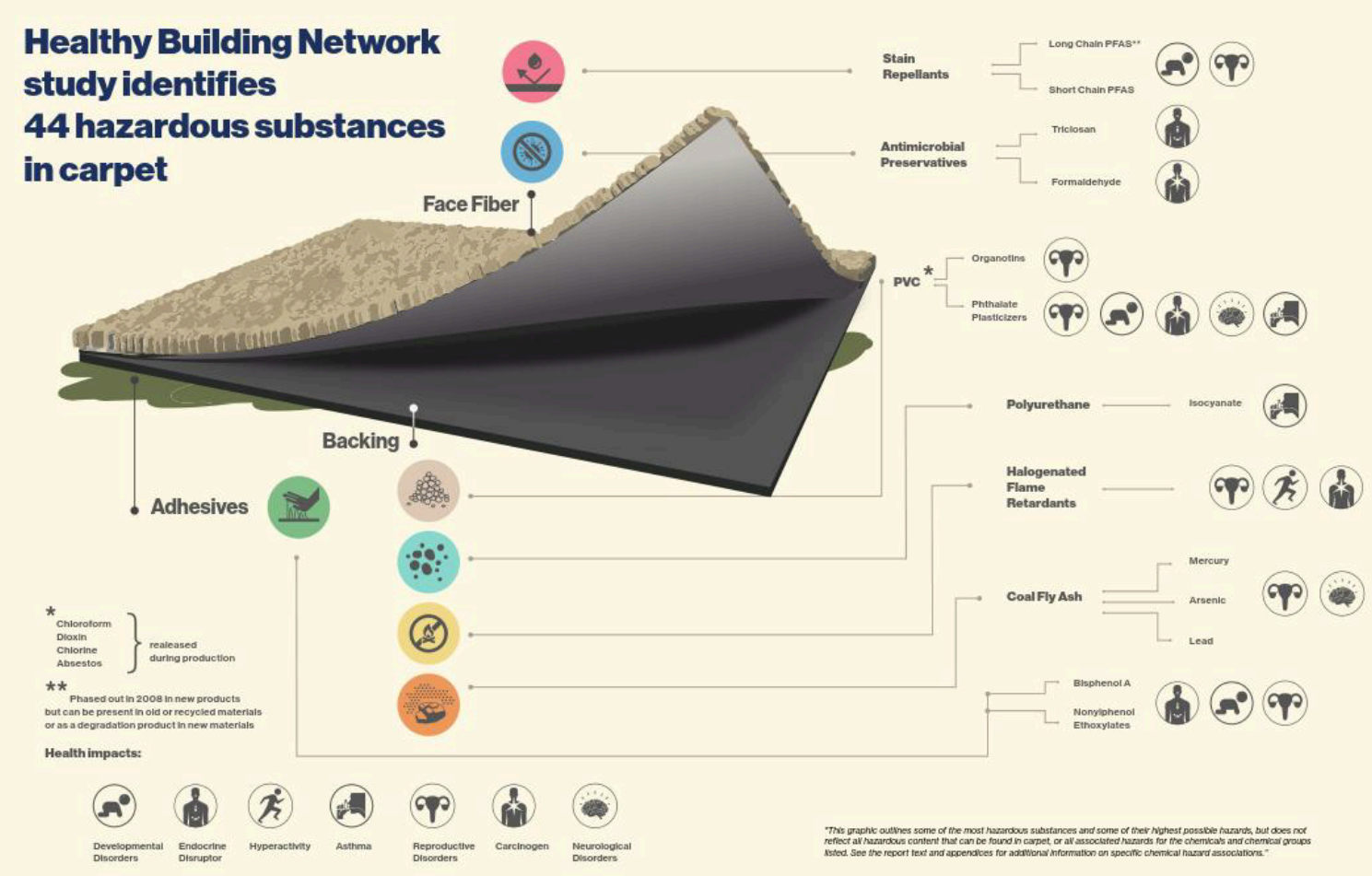

Figure 2: Changing Markets Foundation in Valette, Stamm and Lent (2017)

Given the slow (Nixon 2011), delayed, incremental, and "gaslighted" nature of modern chemical violence, even those harmed by chronic pollution may misrecognize the symptoms; those that recognize it may be perceived or portrayed as delusional in stories worthy of Hollywood noir. When people speak colloquially about "toxic" schools, workplaces, and relationships, they typically refer to social environments whose power dynamics are manipulated by difficult people (bullies, narcissists, gaslighters, etc.). The script of this article, therefore, opens with gender and critical race scholarship about deeper structures of gaslighting within and by institutions. Similarly casting their critics as crazed, the carpet industry used an eco-label to deflect scientific inquiry into the toxicity of its product for almost three decades. In the interim, believing it to be green, thousands of school districts have installed carpet. Culpabilities for this toxic tragedy can be partly attributed to the undone science of indoor air pollution and disinterest in how pollution moves across borders. Further investigative research in the "cold case" of EPA's own toxic carpet episode revealed an unexpected villain with a smoking gun that connected the EPA's failure to regulate the carpet industry and the promotion of carpets to 
school. Following an account of my own school district's carpet drama, a hopeful finale awaits the patient reader.

\section{Gaslighting, Some Theoretical Illuminations}

For most of human history, lighting fuels were naturally derived (olive oil, whale oil, nut or seed oils, beeswax, beef tallow, etc.), but leerie-lit lamps with industrially-produced gas began to illuminate the industrial worlds by the 1820s. Factory pollution from coal-fired gas production triggered the earliest Victorian environmental case law (under "nuisance" ordinances) (Tomory 2012). Tar by-products of the coal plants also began to supply the synthetic production of dyes, glues, and perfumes that are now some of the key sources of indoor air pollution. The carpet industry, incidentally, "recycles" coal incinerator fly ash as a filler in carpets, thereby contaminating them with lead, mercury, and arsenic (Lent 2012), for which there are no safe exposures in children. Suffice it to say, the ins/outs of pollution have always been intimately interconnected, even if scientific paradigms later bifurcated them.

The social concept of "gaslighting" derives from a 1938 play set in foggy London, then made famous by a 1944 film adaptation starring Ingrid Bergman. To steal her family jewels, the husband attempts to institutionalize his wife by slowly manipulating contextual details of their home like dimming the gas lights to convince her that she is mistaken, delusional, and clinically insane. A serendipitous Scotland Yard investigation into a cold case reveals her husband's criminal intentions and Bergman is vindicated and freed from the mental abuse. Psychologists adopted the term in the 1970s to describe how victimizers like child abusers or verbally violent spouses externalize blame onto their victims. Narcissists employ similar tactics to wear down their targets, isolate them from friends and family, and convince them that they are "overly sensitive," "overreacting," imagining things, paranoid, or even insane (Abramson 2014).

Barton and Whitehead (1969) first introduced the Victorian theatrical plot of the "gaslight phenomenon" into the medical literature to recommend that psychiatrists make home assessments before committing patients to asylums to avoid erroneous institutionalizations signed by felonious relatives. Yale psychotherapy scholar Robin Stern further popularized the "gaslight effect" in her eponymous 2007 book about how this particular type of emotional abuse causes the victim to question memory, perception, sensory inputs, and even his/her own sanity. Gaslighters mislead and destabilize their victims' sense of reality and self-esteem by trivializing, minimizing, projecting, denying, twisting, filtering, and suppressing information. Gaslighting, in short, is the attempt to rewrite another person's reality. As survivors of abuse know, batterers (whether verbal or physical) know how to combine their assaults with sufficient charm to sustain the relationship (Waldman 2016). Over time, this unbalancing mix leaves victims doubting their own perceptions and mistrusting their judgments. As small creatures shaped by magical thinking, children are particularly vulnerable to gaslighting.

Are aggressors aware of what they are doing? In debates among psychologists about "confabulation," Spear (2018) asserts that because abusers may selectively filter memories or information, they may perceive themselves as honorable. While the abuser's self-awareness may 
be of psychological interest, for me the more interesting sociological question is how they get away with it. As Paige Sweet (2019) suggests, the grease of gaslighting is social inequality. The projection of blame works best in power-laden settings in which the victim internalizes the sexist/racist structures of the dominant society. When protected by privilege, perpetrators can insist upon their epistemic innocence. As she notes, "abusers mobilize gendered stereotypes; structural vulnerabilities related to race, nationality, and sexuality; and institutional inequalities against victims to erode their realities" (Sweet 2019). Feminist scholars have long demonstrated how gendered ideas of women's "irrationality" and "hysteria" were built into legal, medicinal, and business institutions that normalize white masculinity. More recently the Black Lives Matters movement has challenged us all to scrutinize structures that pathologize those who resist institutional racism (Davis and Ernst 2019). In a poignant piece, "Dear White America," Bjerstedt (2016) intersectionally transforms her own experiences of domestic verbal abuse into a critique of how institutions and media systematically deny, avoid, or conveniently forget historic atrocities against people of color. Whether Indigenous, Black, or Brown, people of color are perpetually gaslighted by a white settler state.

At its far extreme, gaslighting is a tool used by sociopaths, but in diluted form, it is the usual way of doing business for many institutions. It is systematic but also systemic-what STS scholars might describe as a "regime" that perpetuates paradigms through a particular type of circuitous institutional power complex. If, in its interpersonal form, a gaslighter prevents or actively thwarts his/her/their victim from seeking remedy or outside intervention, so as "to destroy even the possibility of disagreement-to have his/[her/their] sense of the world not merely confirmed, but placed beyond dispute" (Abramson 2014, 1), then it can be useful to examine how, likewise, those in bureaucratic power may similarly insulate themselves through groupthink (Janis 1982), strategic deployment of ignorance (Shapiro 2014), or other "controlling processes" (Nader 1996) to destabilize or discredit their environmental critics and invisibilize the harm. Like social gaslighting, problems of indoor air quality are slow, corrosive, and may be hard to disaggregate from other public health problems compounded by institutional racism and historical impoverishment, as described more below.

\section{The Great Indoors}

Through the nineteenth century, both doctors and tenement reform activists regarded the indoors as the source of illness. However, after a cold inversion called the Great London Smog of 1952 killed an estimated 12,000, both the British and US governments respectively passed Clean Air Acts in 1956 and 1963 that focused on criteria air pollutants in the outdoors. Since then, legions of scientists have developed sophisticated linear regressions to predict and monitor outdoor air quality by geography, time, season, traffic, and even sunlight exposure (with ozone levels highest in the afternoon). Many more regulators, lawyers, and community activists diligently monitor the 4.1 billion pounds of toxic chemicals legally released outdoors each year in the US from industrial sites. However, ten times that number of chemicals-an estimated 42 billion poundsare brought daily into our indoor lives, largely through consumer products that we relentlessly 
touch, wear, eat, and sleep upon in our homes and places of work (Smith and Lourie 2009: 10). Pollution is not just something "out there," but also inside our bodies.

My moonlight—or, perhaps more apropos, lamplit-activism on carpet and school air quality once seemed remote from my daytime scholarship as a cultural anthropologist on the enclosure of agrarian environments in Guatemala. However, it was Elizabeth Hoover's (2017) elegant depiction of disempowering, psycho-social effects of pollution, as well as the Mohawk community's inspirational partnership with environmental health scientists that inspired me to re-trust my own relational, motherly intuition about toxic indoor harm. I also began to recognize "the great indoors" as another type of enclosed geographic space from which to consider the classic subjects of scale, nature, place, and power in interdisciplinary political ecology (Biehler and Simon 2010). Not only has American cultural and familial life migrated indoors, but as visible outdoor air pollution worsens in global megacities, much of humanity necessarily spends or aspires to spend a growing proportion of time and breaths indoors (ibid.). The enclosure of domestic life has gendered implications for women's reproductive labor under neoliberal reconfigurations of state, society, and corporate power. In this new confinement to the home or other institutional settings (daycare, schools, indoor sports, and more), children suffer disproportionately from the decline in public space (Ansell 2009)-trends, of course, only magnified by the 2020 COVID-19 pandemic.

From feminist analysis, however, in almost the same breath, I would note that borders can be malleable. As Biehler and Simon (2010) caveat:

The physical walls that enclose such spaces suggest impermeability, but, as with outdoor spaces, assumptions of complete enclosure are fallacious. Inside and transcending the bounds of any building are networked social, economic, and ecological systems that engage human bodies, animals, plants, and microbes both welcome and unwelcome; air, water, and their pollutants; and building materials, infrastructure, and furnishings. (173)

Pollutants themselves are often defined as substances that traverse boundaries. As anthropologist Mary Douglas (1966) argued in her germinal study of purity as a cultural construction, dirt lies in the eye of the beholder. When "clean" substances cross socially established boundaries, they may become polluted and vice versa. Because pollution is residual matter rejected from our "normal scheme of classifications," people are troubled/worried by substances from the outdoors brought indoors, or the indoors brought outdoors, or the indoors mislocated in the indoors. As Fortun puts it, "sludge is supposed to stay in the sludge pond" (2014). The indoors is supposed to be "safe" from the world.

While gross estimates suggest that indoor air quality (IAQ) typically is ten, even a hundredfold worse than outside air, ${ }^{2}$ remarkably little research focuses on how VOCs traverse borders or persist in gendered home environments or institutional contexts. In part, this is

2Of course, "indoor" time can also be mobile. Americans now spend at least an hour technically inside sealed vehicles, whose "new car smell" may contain VOC emissions several magnitudes higher than outdoor tailpipe emissions from even the most jammed LA highway. 
because the dynamic chemical mixtures of indoor air spaces are so scientifically difficult to capture and almost impossible to prosecute legally (Dickson 1994). As Murphy (2006) emphasizes, the very definition of a "sick building" derives from the very impossibility of defining a specific cause for the inhabitants' ailments. Because our regulatory structures have no mechanisms for assessing the synergistic harm of chemical mixtures, sick building investigators must rely on thresholds for single chemicals based on occupational workplace data or what they actually call "lamppost" data-that is, chemicals which are more easily quantified, but which may or may not be the actual causes of morbidity. Even more amazing, when measuring for indoor pollution, technicians calibrate their machines according to "normal" or more "objective" outdoor pollution. ${ }^{3}$

Not until the mid-1970s did the influential private Bell Labs initiate indoor air quality research-not because of human health concerns, but simply because their telephone wires were corroding at unusual rates in American homes (Twilley 2019). Indoor air captured a bit more attention in the 1980s after ASHRAE (the Association of Heating and Cooling Engineers) responded to the energy crisis by dramatically reducing outdoor ventilation standards, resulting in a rash of "sick buildings" (Murphy 2006). Among them was the Environmental Protection Agency's own headquarters where a fifth of the workforce fell ill in 1987-88 after new carpets were laid.

\section{An Off-gassed and Gaslit EPA}

While the longer history of the EPA carpet scandal is beyond the scope of this paper [but see Duehring 1994; Johnson 2008; Lawson 1993; Murphy 2004; and Grandia (forthcoming)], some of its other indoor/outdoor ironies are worth repeating. The earliest impacted EPA workers were from a division assigned to investigate hazardous waste sites. In other words, they were people who felt fine in some of the most contaminated outdoor places on earth, but were immediately stricken ill by their offices.

After nine months of failed negotiations to remove the carpet, EPA unions secured an investigation led by one of the world's first indoor air scientists, Dr. Lance Wallace (EPA 1991). His team initially described it as a problem of "tight building syndrome." After the oil embargo, to conserve energy, the EPA had reduced its fresh air circulation from 15 cubic feet per minute (CFM) to just 5 CFM. In practice, the air circulation was even less, because the blowers turned off at 3:30 pm, even though many employees regularly worked until $7 \mathrm{pm}$. In certain overcrowded offices, desks and filing cabinets completely blocked air vents. As Local 2050 union president, Dr. Bill Hirzy, remarked, the stagnant energy-saving building was like "a gas chamber" (personal communication). Desperate workers brought in their own personal air filters until forbidden to

${ }^{3}$ There are other dirty secrets and contradictions in outdoor pollution studies. Although "big data" sets from the latter are represented as being impeccably objective, these measurements actually rely upon technicians' embodied calibration and "feeling for error," as well as the hunches of scientists in "cleaning" the data (Garnett 2016). 
do so by chief of EPA's Health and Safety Division-ostensibly to avoid outdoor air pollution associated with the production of electricity (Johnson 2008).

When the carpets were at long last removed two years later, EPA began to note indoor air quality as one of the nation's top four environmental concerns (Soviero 1992). As far back as 1984, Congress had instructed EPA to explain why they were receiving so many indoor air complaints. In trying to understand why EPA dropped the ball on carpet, I discovered a smoking gun worthy of Hollywood noir: the very same man, Michael A. Berry, tasked with directing EPA's Indoor Air Quality research program between 1986-1994, already had friendly relations with the carpet industry based on speaking engagements and self-cited work for carpet cleaners in his annual reports (Berry 1990). When he retired, those connections became overtwith the Carpet and Rug Institute hiring him specifically to promote carpet in schools and hospitals. Wielding the credentials of being a retired EPA director, he organized a conference of pro-carpet advocates at University of North Carolina's business school, where he taught as an adjunct professor apparently even whilst employed by EPA. In those proceedings, he insisted that "the science clearly indicates that modern carpet is manufactured to be environmentally safe and that clean carpet poses no risk to public health" (Berry 2003, 14)—whereby he cited the dearth of contrary evidence from EPA that he himself failed to produce as a deputy director tasked to "identify and coordinate research needed to fill existing information gaps" in indoor air science (Berry 1990, 35). In June of his retirement year, he was already amplifying the carpet industry's counterattack against environmentalists in academic journals by citing his own managerial negligence in pursuing research into the carpet industry as proof of its safety. For example:

\begin{abstract}
Although no credible scientific or medical evidence was uncovered by the U.S. Environmental Protection Agency (EPA) or independent testing laboratories to show that carpets are a cause of multiple chemical sensitivity or allergic reactions in humans (the "sick-building" syndrome), continuing claims that carpets may be a cause of chemical irritation required carpet manufacturers to take measures to reassure customers of the safety of their products (Rondinelli and Berry 1998, 23).
\end{abstract}

Across various other fora, he gaslighted blame for environmental illnesses from chemical emissions to poor custodial services and "wetness" in schools. Berry later specialized in mocking "perceptions" of environmental health concerns about industrial chemical cleaners as "junk science" and "eco babble" (Cleaning Business Magazine 2007). A white paper he authored for the Carpet and Rug Institute was entered as evidence during a rare Congressional committee investigation into environmental problems in public schools (107th Congress 2002). Manipulating fluorescent lights rather than gaslights, he argues that "glare from hard surfaces is distracting" and carpet, therefore, helps children "focus on the front of the classroom." If properly vacuumed, "carpet floor coverings are essential in making classrooms work" and

4 In a keynote address that might cause Mary Douglas to turn in her grave, as an evident germaphobe, he asserts that green cleaning is "all about polluting" (Berry 2010: 22). 
improving educational performance (Berry 2002, 3 \& 15). He repeatedly vouched for the healthfulness of properly vacuumed carpet, "You could eat off it. It's just plastic. That's what you want your kids crawling around on..." (Berry 2010,19)

Beyond Berry, the rest of EPA's indoor air research and regulatory team was absurdly small with just 15 full-time staff. From that group, the person who eventually took helm of EPA's indoor air quality program was the same senior staff scientist (Bob Axelrad) who thwarted Local 2050's proposal to regulate 4-PC carpet emissions (Hirzy and Morison 1991) during a 51-meeting "dialogue" with carpet industry (Grandia forthcoming). After that, Axelrad was noted as a key contributor to the "Schools Action Kit," which endorses the Carpet and Rug Institute's green labeling program (Thompson 2000). It provides zero warning about potential hazards to school administrators.

Thirty years later, Axelrad continues to lead EPA's IAQ division. Rather than investigating toxic consumer products that can be traced back to specific corporations, the division focuses on more "natural" (and perpetrator-free) threats to indoor air like radon, dust mites, roach droppings, mold, or domestic cooking emissions (Twilley 2019)—again, with tacit gender blame shifted to sloppy housekeeping. Even before Trump eviscerated the EPA, its Obama-era website reflected minimal attention to the volatile synthetic chemicals off-gassing from interior designs, renovations, and maintenance. Meanwhile, outdoor air continues to consume the lion's share of federal research, regulatory dollars, and scientific brains. Micro-soot $\left(\mathrm{PM}_{25}\right)$ became the new hot topic at EPA, while much higher rates of chemical dust and fumes inside homes and schools were ignored (Allen and Macomber 2020).

\section{Ins and Outs of Pollution}

Yet, soot is no longer as simple as Percivall Pott's (1775) foundational occupational study of scrotal cancer in chimney sweeps (Sundell 2004). Outdoor particulate matter now includes synthetic molecules known as volatile and semi-volatile organic compounds (VOCs and SVOCs) derived from fossil fuels. By definition, they are chemicals with low boiling points that form gases at room temperatures-physical properties that also make them very reactive in the air. In the presence of nitrogen oxides, VOCs degrade through diverse chemical reactions into secondary aerosols. They eventually will break down into ozone, $\mathrm{CO}_{2}$, and water (some over minutes, others over months), but in their unstable, intermediate stages, these dynamic aerosols can produce adverse effects on human and wildlife health. Although it was once difficult to capture this chemical complexity, advances in mass spectrometry now enable air quality scientists to "fingerprint" and measure the thousands of different structures of VOCs (Lewis 2018) that compose fine particulate matter in the air. Yet, are they looking in the right places?

Although tailpipes and smokestacks are the stereotyped origins of city smog, a startling study of Los Angeles pollution suggested that everyday indoor consumer products accounted for an astonishing half of that city's infamous pollution. Led by Brian McDonald, a US National Oceanic and Atmospheric Administration (NOAA) team was puzzled by high levels of volatile organic compounds (VOCs) in Pasadena air that could not be linked to vehicular combustion 
(Carswell 2018). By combining traditional roadway measurements with data from California Air Resources Board on consumer product emissions (specifically pesticides, coatings, printing inks, adhesives, cleaning agents, and personal care products), the team concluded that VOC emission factors from people's own bodies, homes, and offices were "one to two orders of magnitude higher than from automobile exhaust" (McDonald et al. 2018). News editors frolicked with this irony in headlines like: "Smog Has As Much Deodorant As Diesel In It" (Forbes) and "Shampoo is Causing Air Pollution, but Let's not Lose our Heads" (New Scientist). Put another way, the US dedicates fifteen times more petroleum to vehicular combustion than to making consumer products, but the latter emit roughly the same amount to VOCs into urban air as the former.

This is true even for some of California's most polluted "airscapes."s The "Northern California Household Exposure Collaborative" discovered that homes around the infamous Richmond refinery actually had higher $\mathrm{PM}_{25}$ levels indoors than outdoors, even during flares requiring "stay inside" (shelter-in-place) orders (Brody et al. 2009). In another remarkable study, they compared the indoor air pollution of a wealthy coastal community (Bolinas) with that of Richmond's poor neighborhoods and found disturbing levels of indoor air pollution in both-to the surprise of study participants who misperceived the home as a safe haven (Adams et al. 2011).

As Michelle Murphy has emphasized through her concept of "alter-lives," indoor threats to even wealthy communities may be imperceptible because of the permanent chemical alteration of post-industrial bodies. Odors may provide warning of harm, but not always, as chemical corporations add synthetic fragrances to their products to mask other dangerous odors. In memoirs, social media testimonials, and quiet conversations among folks with environmental illnesses, they/we describe the experience of coming to chemical consciousness as something like un-peeling onion layers to "unmasking" the deeper causal threat(s). As any person who returns home from a long vacation may note, an empty house smells newly strange until one has reimmersed sensorially to the habitat. In other examples of olfactory adaptation/smell fatigue, people with body odor may not smell themselves; the overly perfumed cannot perceive their own pungency; and so on. In her pathbreaking theory of "Toxicant Induced Loss of Tolerance (TILT)" Miller points to inflammatory "masking" as a key etiological problem in diagnosing the external causes of environmental illnesses. As Nading (2020: 210) puts it, "toxic effects seem more like affects." When people are chronically habituated to irritants or suffer apposition (successive or overlapping reactions), they may misperceive the cause or be mislabeled as inherently "sensitive" rather than having been sensitized by chemical injury.

s For the concept of "airscapes," I was inspired by British artist Michael Pinsky's dome installations that contrast air from the Norwegian countryside with Delhi, Beijing, London, etc. (Yeginsu 2018)

- To be sure, a sense of home is not always indoors. In trying to understand the affects of contaminated places, the juxtaposition of industrial pollution on a Chippewa reserve in Ontario, Canada, Jackson (2011) describes this profound sense of alienation from ancestral homeland as "dysplacement." 


\section{Methods}

In using this story about carpet injury to rethink the above air pollution paradigms, I was inspired by "creative tension" in Sandra Steingraber's autobiographical style that blends hard toxicological science and cultural critique with the ecology of family (Bryson 2001). I also share her sense of the deep mobilizing power of maternal care (Brown 1992). Motherly worry has certain atmospheric qualities-a kind of "suspension" from the present to project concern into the future (Choy and Zee 2015). Feminist time studies demonstrate that the work of worry is a capitalist externality that falls disproportionately upon women (Schulte 2014). While some worry can be productive, anxiety reflects an overload of external quandaries relentlessly lodged into the brain about which a person can do little.

Dominated by technical disciplines, early hazard studies once assumed that scientists (engineers, doctors, statisticians, epidemiologists) understood the "real" risk, while the "perceived" worries of the public were subjective, uninformed, false, illusory, or irrational. STS scholars began to question this hierarchy, noting that scientists themselves disagree. Meanwhile, following their intuition, like the mothers of Love Canal, the public began collecting their own data through citizen science. Through worry as proxies for their little ones, mothers, teachers, and caretakers must necessarily pay close attention to the details of our children's health and humor to recognize incremental threats that others might see as harmless (Rudestam et al. 2004). Squatting to talk to children, we understand that children have a bodily intimacy with surrounding airspaces and niches into which adults do not fit (Ansell 2009). Private kitchen table discussions about embodied exposure experience (Adams et al. 2011) therefore remain an essential consciousness-raising zone for transforming maternal worry into public environmental justice. Perhaps more than any other type of anti-toxics organizing, the "intimate activism" (Tironi 2018) of mothers is driven by ethics of "agency-as-obligation" (Liboiron, Tironi, and Cavillo 2018).

As an inductive medium that shares an appreciation for the observational knowledge of citizen science, ethnography is a prime medium for "worrying through" (Fortun 2012) intellectual problems. In turn, auto-ethnography illuminates emic perspectives not perceptible to even the most sympathetic or allied observer.s More than the filtered haze of memoir, autoethnography implies that one has taken pro-active care to record detailed notes and triangulate them with additional documentary research. As a self-same process of participant observation, it shares attention to experiential detail.

That said, none of this carpet investigation was planned as academic research. It was, first and foremost, a single mother's extracurricular struggle to protect her only child from bodily

\footnotetext{
- At one point in the struggle, we contacted the teachers' union, which chose to remain uninvolved. However, because the union representatives used district emails to communicate with us, we later learned from public records that they were reluctant to attend a meeting inside a private home-an odd excuse since unions have always organized through meetings around kitchen tables away from the bosses' ears.

- As I am learning from my Native American graduate students, anthropology is no substitute for indigenous epistemology. This is not a question of blood quantum, but how emergent Native scholars are building new kinds of theory through embodied insights illuminated by transgenerational mentoring and wisdom.
} 
harm. Nonetheless, the tools of good activism are remarkably similar to those of good qualitative research. In retrospect, I can see they also share similarities with therapeutic recommendations for victims of gaslighting.

- Refer to history (recollect one's sense of self prior to life with an abuser).

- Take careful note to reestablish control in asymmetrical power situations.

- Check facts and document everything.

- Triangulate/validate observations with outsiders or third parties.

- If possible, step away from the context for perspective.

- Make use of legal tools for investigation.

Following similar defense principals for our carpet-removal campaign, I corresponded with a multitude of experts and interviewed several octogenarian actors from the EPA's own 1987-88 carpet scandal who (like me) kept scrupulous archives that they generously shared. I connected with the authors of unfolding nonprofit reports on the carpet industry that documented a shocking 43 hazardous substances in carpet (Valette, Stamm, and Lent 2017). As illustrated by Figure 2, these include a carcinogenic styrene butadiene latex that binds fibers to a toxic backing that contains PVC, phthlates (plasticizers), BPA, and residual heavy metals from coal fly ash filler. Additional toxic coatings on the fibers include: antimicrobials (triclosan banned in personal care products but permitted in carpets); flame retardants; PFAs and PFOAs ("forever chemicals") for stain resistance, which are linked to illnesses ranging from testicular cancer to thyroid disease, as well as several thousand lawsuits against Dupont; and even perchlorate, a chemical used in rocket fuels that is associated with cancer and thyroid issues. Many of these were discovered in even the carpet industry's most "eco"-friendly lines and brands (Changing Markets 2018). I called flooring companies; queried salespeople; screen captured the Carpet and Rug Industry's website for years; and cultivated conversations with an industry whistleblower. As a last resort, another mother and I filed a battery of public records requests to understand the school district's inner logic.

I also drew from past embodied experiences of carpet-related environmental illness (Grandia 2020) that enabled me to immediately recognize symptoms in my daughter and to dialogue with other mothers about their children's ailments-in ways not possible in traditional ethnographic research. As developmentally dynamic and often mercurial beings, children are especially vulnerable to the masking of toxic harm, especially neurological effects. Beyond classic allergic responses (eye irritation, stuffy nose, skin rashes, etc.) to common chemical irritants, children can also suffer cognitive and emotional transformations (cf. Randolph 1962). As documented by environmental pediatrician Doris Rapp (1997) in chamber studies, toxicants can not only trigger a limbic "fight or flight" response, but also anger from the amygdala. Parents can easily dismiss as "just a phase" the kinds of irritated outbursts, muscular aches, nervous tics, cognitive decline, poor handwriting, and other flickering emotional gaslights that the Beacon

- At a national level, journalists are using similar tools to deconstruct Trump's twitter feed. 
mothers observed in our children after the new carpets were installed. In unusual moments of friendship and emotional vulnerability, we confided to one another how our once cherubic children came home from school so chemically addled that they began punching their mothers in the face. Had their brains been injured, were we bad mothers, or were we just imagining things? Much as therapists recommend to gaslighted clients to write a comprehensive counterstory for "narrative repair" (Waldman 2016), the nonfiction sketch that follows represents a final step in our struggle to reclaim agency and clear the air.

\section{Clearing the Air}

Having experienced a "carpet bombing" at my first university (Grandia 2000), when I moved to California, I bought an old house with hardwood floors. Unable to find daycare centers without carpet, I juggled my daughter's preschool years at home. Her first exposure to institutional carpet was, therefore, in kindergarten. To my repeated horror, she came home from the first day of school with welts on her legs. Without other schooling options, I thereafter dressed her in leggings and tights, bought an air filter for the classroom, and tried not to worry. When redelivering that filter two years later to her new second-grade teacher at Beacon Elementary, the stench of new carpet smacked me in my tracks. With horror, I realized that my introverted daughter's after-school stomach cramps, headaches, twitching, myalgia (muscle pain), crying jags, listlessness, and exhaustion that week were not from the presumed social stress of a new school year, but the wretched indoor air quality of her classroom (cf. a similar set of symptoms reported in Norbäck and Torgen [1989] or Anderson, [1997] for studies of carpet exposure in rats).

Compounding the situation, northern California temperatures climbed the following week into the 110s. Smoke spilled down from the Shasta/Trinity wildfires and lay trapped in the valley. Yet even as $\mathrm{PM}_{25}$ levels soared past red into unprecedented magenta alerts that same week, the newly carpeted classroom air reeked far more than the outdoors. A grandmother in a calm respiratory state waiting outside with me in the hazy schoolyard then suffered an asthma attack after stepping inside the classroom for just a minute. I found myself oddly hoping the principal would not cancel outdoor recess due to the smoke, so the children might have at least some temporary relief from the carpet fumes.

Terrified, I immediately filed a formal complaint to the school district and requested an immediate increase in the air circulation. Fearful of the long-term repercussions of carpet injury, I quickly decided to offer my daughter's college savings to the school district to immediately remove the carpet. A few days later, I secured a second donation for a classroom's worth of "marmoleum" (natural linoleum) tile from one of the eco flooring companies I called for replacement quotes. 


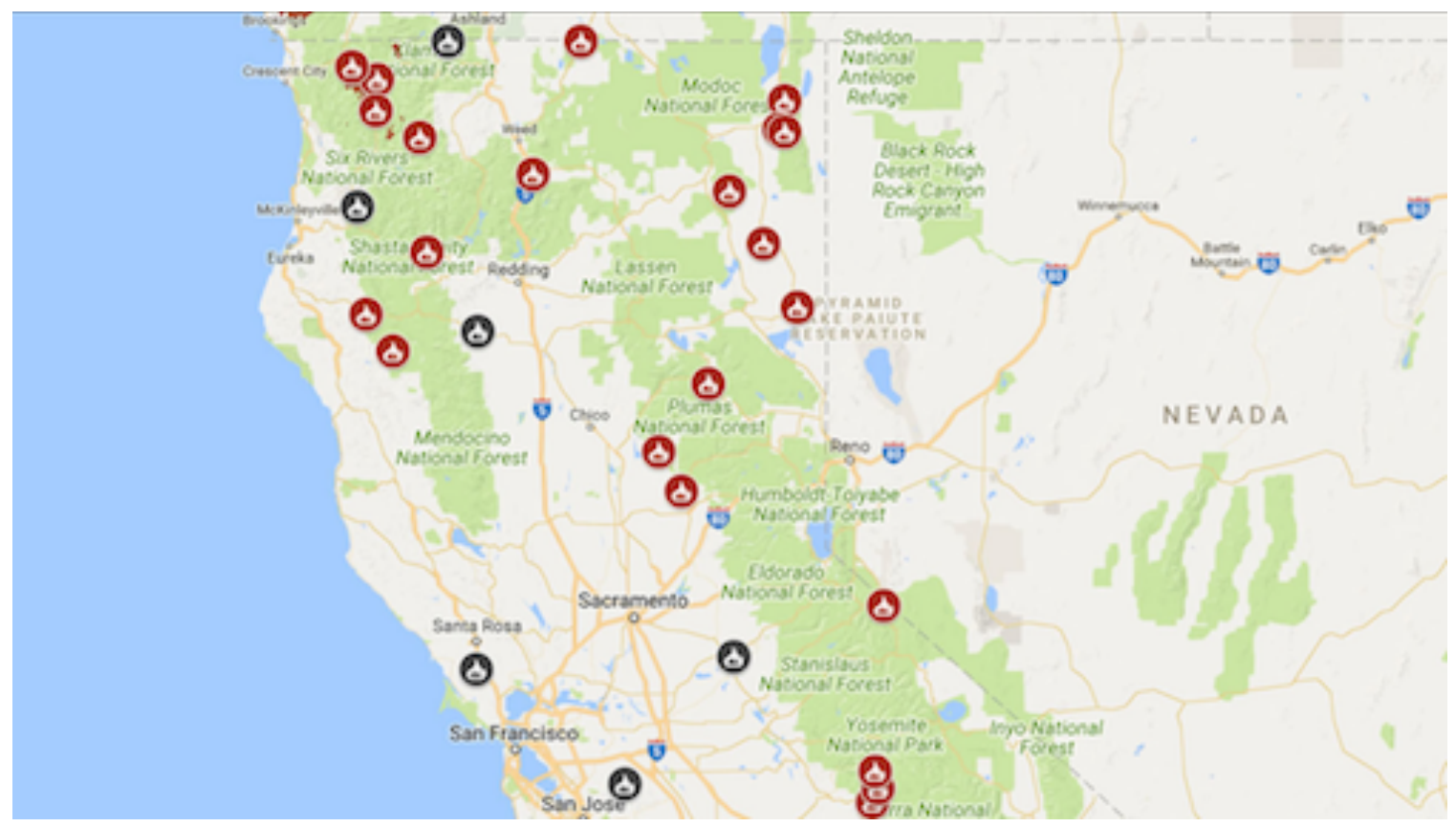

Figure 3: 2017 California Fires

The school district declined both my donations. They said, Ms. [sic] Grandia, if labeled "green," the carpet must be safe.

I began to mobilize for a one-woman-activist-carpet-show. Teacher after teacher began to approach me in the schoolyard to whisper about the stench of that room and other air quality concerns, including a history of mold problems throughout the portable trailers. They wondered if they should just mask the carpet fumes with Febreze or plug-in air "fresheners" (please no!). In those conversations, I learned that the teachers were forbidden to leave open doors and windows for fear of school shootings. Yet, in defending against external "stranger danger," the schools had inadvertently intensified another kind of chemical violence to children's and teachers' bodies.

Preparing to take my concerns to the school board, I met some other mothers from the school who were petitioning for an air conditioning system after children collapsed from heat strokes in the after-school program. The school with the highest Mexican-American enrollment was also the only one in the district without $\mathrm{AC}$ in its multi-purpose room. I became friends with the HVAC petition group, and in solidarity with me, they signed up for my "coalition for green schools." An illegal pesticide spraying incident at Beacon Elementary in October recruited more upset mothers, many of whom were daughters or granddaughters of farmworkers. Then, in November, we learned that the same new carpet had been installed over the summer in three other classrooms. Some of the HVAC mothers belatedly made a connection between the carpet in those classrooms and changes in their children's own health, including stomach aches, headaches, red eyes, concentration and memory problems, fatigue, and declining grades. We 
eventually tallied a list of eight chronically sick children (adding three more later) for a total of eleven among the four classrooms in both the before and afterschool programs.

Intense months of organizing followed. Carpet was a formidable issue with which to mobilize a movement for "green schools." It was challenging to create an "event" out of the deeper problem of decaying school infrastructure (Ahmann 2018). So, in early December, the mothers and sick children marched down Main Street in the holiday parade as proverbial canaries in the mineshaft (Figure 4). A young newspaper reporter for the local paper picked up our story and accompanied us to a December meeting with the school district, where at last the Superintendent agreed to accept my two donations and match them to remove all four carpetsor so we thought.

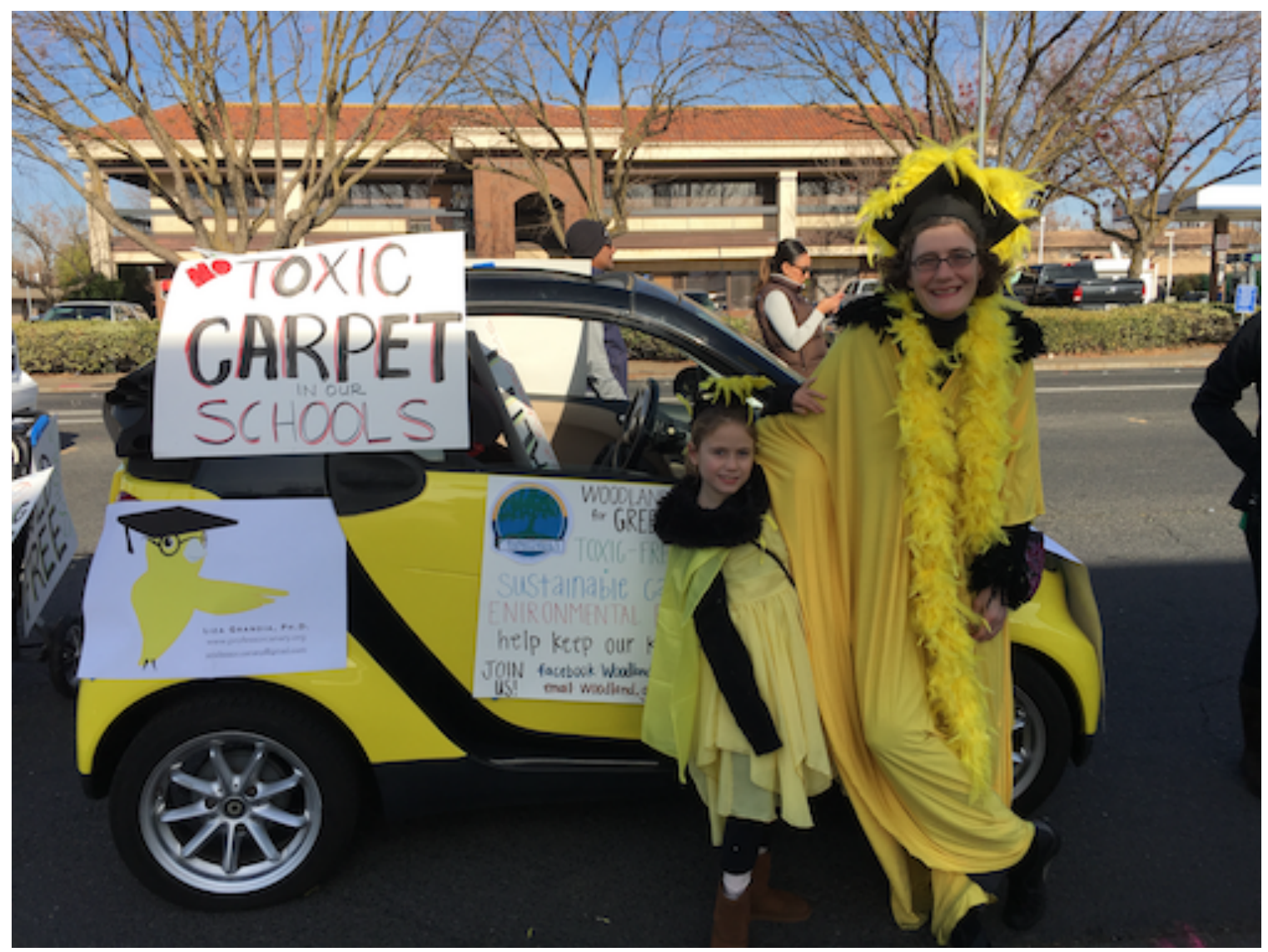

Figure 4: Mama and Daughter Canaries

After the winter break, he disappointed us with the news the donations could only remediate one classroom and the contract for the other three classrooms would need board approval - a routine matter, we were told, but inexplicably postponed to February 8 . We continued our lobby. Before the holidays, two trustees offered to roll up their sleeves to do the 
work themselves if needed. Two others spoke on our behalf, including "Becky," who held a day job in environmental risk management. We thought we surely had four of seven votes for remediation of the other three classrooms. However, given Becky's prior history working for the chemical industry and her self description as a "proud member" of the American Chemical Society, I should have anticipated her politics of disavowal (Fortun 2014).

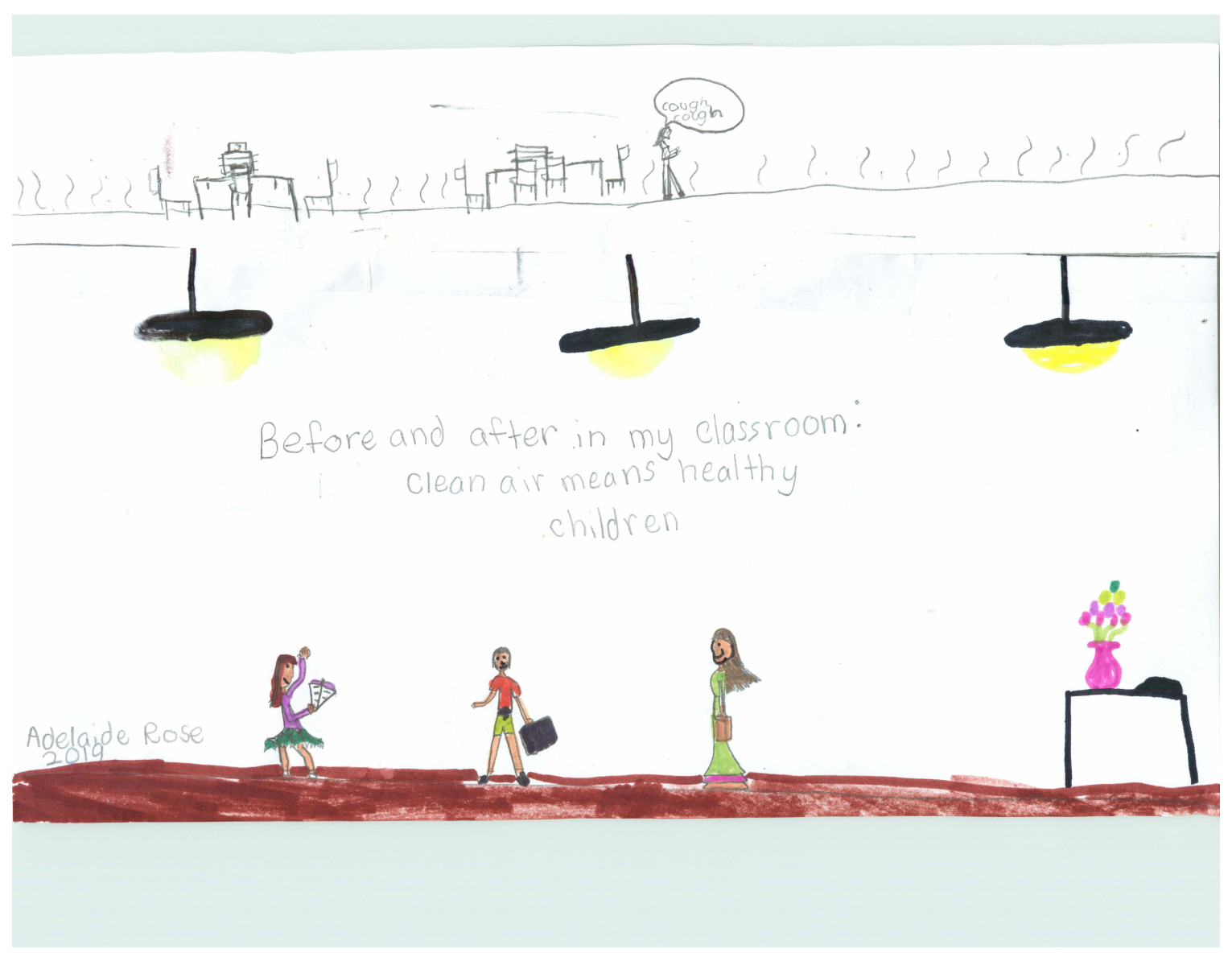

Figure 5: Before and After, author's daughter on the carpet removal

Before the carpet removal from my daughter's classroom in late January, I requested a thumbnail size sample of the discarded material for testing. Claiming potential problems with the chain of custody, the Superintendent responded that "the district is unable to collect or give out samples of the carpet." However, public records later revealed that the district did, in fact, hire a laboratory to place into storage an eighteen square inch sample of the removed carpet. As for the rest, like the Grinch on Christmas Eve, the subcontracted company carted away every last thread in a rental U-Haul. (Other mothers checked the dumpsters the next day ... nary a scrap was left). 
At the February 8 board meeting, the routine budget items were put last on the agenda. The meeting's surreality was heightened by the unprecedented presence of two armed policemen stationed at the doors. The usual two-hour meeting droned for four hours until ten o'clock p.m. Mothers went home to put their children to bed and came back. Some began to worry that none of the trustees would look at us. Nah, I thought, we have this in the bag. It'll be 5-2 in favor of remediation, and then our green coalition will gladly help them pass a sorely needed school bond in the next election. Even if the trustees were not convinced by the health hazards of carpet, when taking into account maintenance and replacement budgets, we had clearly shown that carpet was costing the school district several times more than tile or natural linoleum floors.

At last, the agenda item came. A sympathetic trustee motioned to approve, but no one seconded. What? In a haze, the mothers broke Robert's Rules and demanded discussion. One trustee said the air tests prove it can't be the carpet? Huh? What air tests? Confused, we asked again, what air tests? Huh? The Superintendent had secretly ordered air tests? When? Although the trustees had apparently not seen the results either, they trusted the Superintendent's word that "the results were fine; everything's fine."

The policemen arched their muscles and the president of the board gaveled me into stunned silence. Despite having just discussed the discovery of an unrestricted surplus budget of one million dollars for facilities improvements, the trustees then voted 6 to 1 not to spend $\$ 31,432$ to remove the carpet from the other three classrooms. Five trustees exited out the back to avoid the weeping mothers.

I filed a midnights public records request for a copy of these covert air tests and saw immediately that the "baseline" test in my daughter's classroom failed to screen for the key chemical of concern, 4-PC (4-phenylcyclohexene). The other three classrooms were not tested until six months after the new carpet installation. A California air regulator who reviewed the results as a favor to the mothers wondered why the tests were inexplicably conducted at $11 \mathrm{pm}$, with no observers, and no notes about where the canisters were placed, nor levels of air circulation.

Those questions remained unanswered. That month our sympathetic local reporter gave up journalism and moved to the Bay Area for another career. The town newspaper editor ignored our press release about the air tests. Of a generation convinced of "better living through chemistry" and a former chemistry teacher himself, the Superintendent countered with a press release vouching for the safety of the carpets:

The carpets of concern are Green Label Plus Certified carpets, which meet and exceed the Collaborative for High Performance Schools (CHPS) criteria for low emitting materials. This is some of the best carpet on the market, and it is approved for use in schools by the State. This carpet was installed properly and by a professional installer.

To be sure, carpet companies sit on CHPS's board. Although I had spoken for months about how the carpet industry invented the unverified "Green Label" in 1991 to avoid regulation after the EPA headquarter's scandal, "legality" became the district's mantra. 
Since ostensibly Becky had voted against the carpet removal until the "pilot" classroom could be evaluated, the mothers requested a meeting with district executives in late spring to report notable health and cognitive improvements among the children in the one remediated classroom (illustrated by my daughter) and for another child who was relocated from an unremediated class to a new homeroom My daughter's teacher confided that the whole remediated class's third-quarter test scores were unusually high. She herself was not so fortunate, having just been diagnosed with breast cancer after five months of exposure to the new carpet before it was removed. Facing a new level of liability, the school district went silent.

\section{An Inside View from Public Records}

To break the stalemate, another mother and I filed a public records request, which the district hired an expensive law firm to handle. In the 2,600 pages returned to us, we learned that the new carpet had been installed in not just four classrooms at our school, but another 23 across the district. Behind the scenes, certain trustees described the mothers as "bullies" and "terrorists." The trail of shifting excuses discussed behind the scenes included:

- "Let's go with the 'bad batch" theory..."

- "Time will fix it."

- "How can they prove it's the carpet not something else in the portables?" "

- " "If we fix the carpet, they will ask for something else."

- "It's legal."

- " "If they have a problem with the carpet industry, they [the mothers] should change the law."

- "This is perfectly good new carpet."

Becky, the trustee who works by day as a professional chemical risk manager, appears to have provided key advice to the Superintendent about how to renege on his December 2017 promise to the mothers to remove all four carpets. By email she commiserated with the Superintendent for "heading into the lion's den" to deal with an "ambush" of six mothers who, horrors, cried at the meeting and brought "pictures of students who they claimed had symptoms ranging from red eyes to neurological problems." Agreeing that the mothers' emotional expression "feels like bullying and blackmail," Becky counseled:

There is no empirical evidence the carpet is toxic. We live in one of several non attainment areas the Air Quality Management District monitors closely[.] Our air quality is poor to begin with. In September October we were experiencing one of the worst fires in California history less than 60 miles from us. Of course[,] there would be health effects

\footnotetext{
10 Incomplete polymerization of the styrene-butadiene latex in carpet backing had been implicated in elevated levels of 4-PC in other sick building scenarios (Anderson 1997).

"As noted above, the fourth homeroom with the sickest child was a brick-and-mortar classroom, which meant that the children's illnesses could not be blamed on the portables alone.
} 
from the fires. The carpet manufacturer, Department of Public Health, Consumer Product Safety Commission, California Department of Education, our unions, local medical professionals-none of them have brought any carpet problems to our attention.

Though the children remained ill months after winter rains cleared California's fires, Becky blamed their illness on the outdoor smoke. Full circle, she cleverly understood that outdoor air pollution can always be scapegoated in the public imagination. From the playbook of the tobacco industry and climate deniers, doubt was Becky's product.

\section{Rugrats for Reform}

In the classic, unadorned words of Charles Perrow (1984) about nuclear meltdowns, "The issue is not risk, but power." While public records do not provide sufficient material to speculate on the motivations of the diverse people that enact amateur bureaucratic power on local school boards, it appears most of them just ignored the nonprofit reports and books we gave them and simply trusted the carpet industry's "green label." Decades of relentless corporate manufacture of uncertainty has primed even local public officials to demand proof over precaution. As one trustee impossibly demanded of the mothers, "How can you prove it's the carpet?" Without samples, we obviously could not. Trained in the language of risk assessment and counterfactuals, Becky understood that the board could dismiss their constituents' realities as false. Due to the dearth of indoor air science, in general and in research into carpet, in particular, they would be protected from legal reprisal.

Ultimately, STS is not about disputing the legitimacy of science, per se, but about using a social constructivist lens to "question what [scientists] are measuring and not measuring" (Tarr 2004) - and then reflect upon who benefits and who suffers from the uneven sedimentation of scientific curiosity. If, as DuPuis notes, the "smoke" of air pollution is a "mirror" of social relations of power, my contribution here to that ongoing discussion was to emphasize that our perceptions of contamination and its locations can be easily gaslighted-due to the etiological uncertainties of environmental illness and multiple exposures, but also by the collective (scientific, institutional) disinterest in how indoor air quality may be harming children's emotional and intellectual development. For me, the real villains of this story were the EPA staff members who might have done this research but instead protected the carpet industry's bottom line over US schoolchildren's health and safety (Berry 2010).

Like David Noble in his masterful history of engineering, America by Design, scientific research may be a complex hegemonic system, but one can nonetheless trace its directionality to the complicity of key figures-what anthropologist Laura Nader characterizes as "controlling processes" (1996). Unlike Bourdieus's (1980) smoother notions of power as "conductorless conduct," this carpet story points to how toxic uncertainty can be manipulated at multiple levels. While villainous gaslighters at the top eschalons of power make for good Hollywood drama, the more interesting figures are the supporting characters in the wings. As I quip to my students, pay attention to the anonymous "men in grey suits." Behind the closed doors of conferences, 
clubs, convention exhibits, consulting reports, these middling "grey suits" can orchestrate or ignore environmental crimes largely without repercussion. In modern-day allegory of Plato's cave, chained in the semi-darkness, refusing to read unfolding research of renegades, local institutions can hold fast to their epistemic innocence even when challenged by constituents.

Yet, as we know from popular culture, the final awakening of interpersonally gaslighted victims often results in a breakage-resignations, divorces, disownments. Gaslighted publics also suffer feelings of civic betrayal and distrust of governing institutions following toxic tragedies (Beamish 2001; Szasz 1994). As I conclude this article, millions across the US have taken to the streets in protest not just of police brutality but of an entire system of racialized gaslighting. In less spectacular ways, local environmental crises such as the Beacon carpets can generate momentum to shift structural power imbalances. In fact, one of the Beacon carpet mothers vigorously campaigned to win a seat on the school board and is leading a broader democratization of their decision-making processes based on genuine community consultation. With another new allied trustee, she seized a procedural opportunity in 2018 to call for a new floor policy.

Perhaps the most redemptive character from the final scene of this story is "Scott," the facilities manager who installed the carpet. Early in the mothers' struggle, this was a person who said with a straight face on camera to a local television reporter that he had called the carpet company and was reassured it was safe. I retorted on social media, "Sure, the carpet industry tells you its product is safe. Philip Morris will also assure you that smoking doesn't cause cancer." Although Scott was once clearly gaslighted by the carpet industry into believing the safety of the "green" label, when tasked with writing a new floor policy, he and a new assistant began to read the nonprofit reports and other evidence presented to the board and train themselves about "red listed" chemicals of concern. Building on their excellent draft, we easily came to an agreement on a pathbreaking policy in two short meetings. With precautionary principle sentiment, our joint statement details skepticism for the industry's own certifications, commits to purchasing decisions based on the total cost of ownership, and excludes specific chemicals of concern. The next month when we presented our joint policy together at the podium, several trustees verbally marveled at this outsider/insider alliance (Figure 6). With a pained face, even Becky joined with the others to pass our sustainable floor policy." It is now being evaluated in committee as a model for the whole University of California procurement system.

${ }_{12}$ For the moment, the policy remains aspirational due to budget constraints and numerous other facilities issues ahead of carpet removal. An awakening public, however, has noted that California is among the worst states for the ratio of per capita spending on prisoners $(\$ 64,642)$ compared with public school students $(\$ 11,495)$, and our community will hopefully pass a needed bond for general school maintenance. 


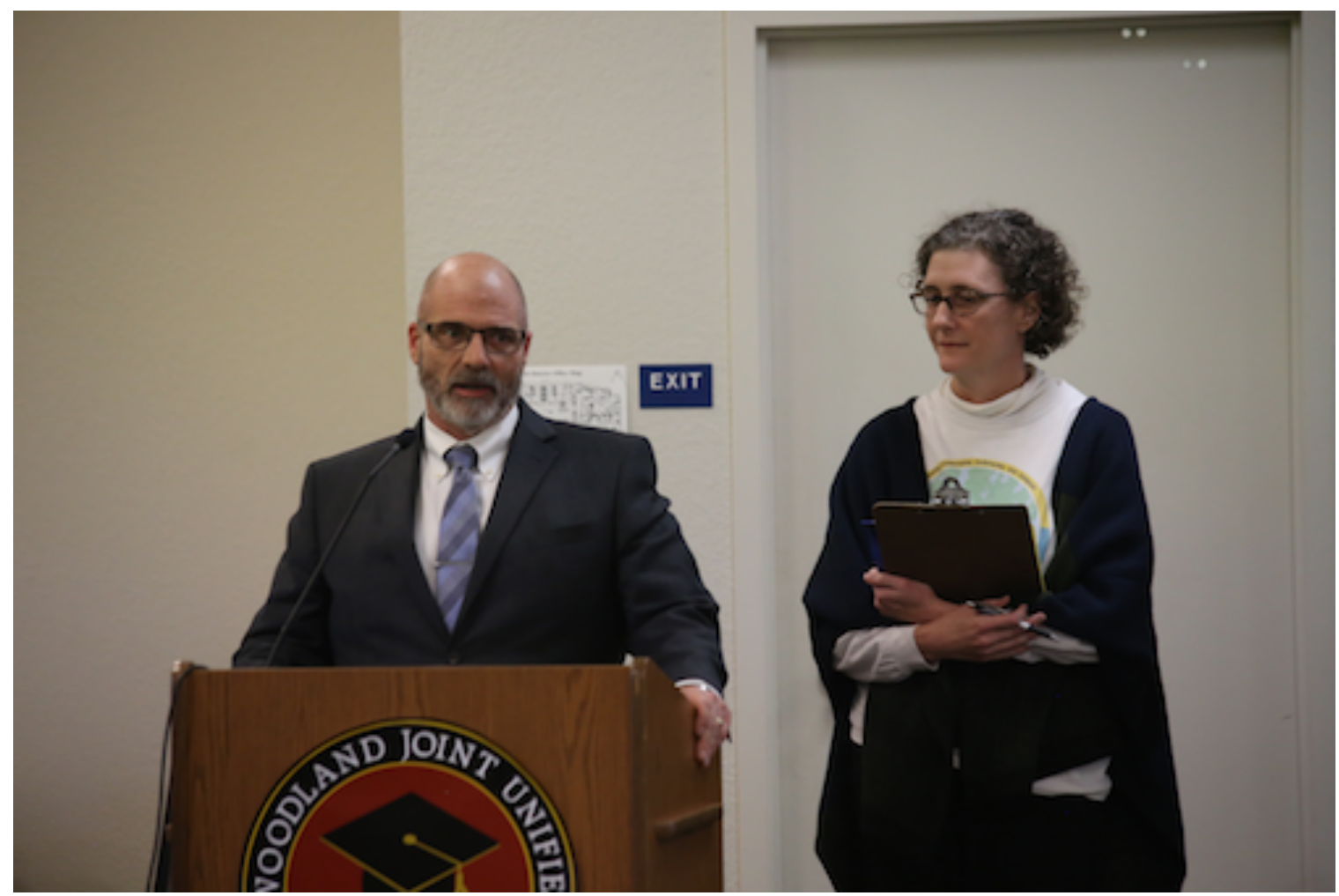

Figure 6: Town newspaper coverage of the floor policy, courtesy of Carlos Guerrero 2019

Meanwhile, two branches of California's EPA have launched separate investigations into flame retardants (PBDEs) and stain repellants (PFAS or "forever chemicals") in carpets-both of which pose special dangers for vulnerable populations like children who share close intimacy with carpet throughout their developmental years. It is my hunch that twenty-first-century ecological revolutions will not arise from the factory but from the frail bodies of child activists like Greta Thunberg and the Beacon children whose labored breaths are awakening my wall-towall comforted and comfortable generation into action. For the investments needed to move the deferred maintenance of late-industrial school districts into sustainability, I hope our story may provide a beacon of hope.

\section{Author Biography}

Liza Grandia, cultural anthropologist, is an Associate Professor of Native American Studies at University of California-Davis. She is the author of several books and monographs on threats to Q'eqchi' territory and autonomy in the northern Maya lowlands into which she is layering a new line of research on pesticides, agroecology, and environmental justice. Making intellectual 
lemonade from life's lemons, she is pursuing a number of projects about cultural perceptions on toxics in everyday life.

\section{Acknowledgments}

To my carpet comrades whose names I protect per standard anthropological ethics, I am grateful for the friendships we developed through this struggle. Alysa Meyer of Legal Services of Northern California aided two of us in filing public records requests and an appeal to the state. Sierra Club's recognition of our coalition as northern California's "best activist group" of 2019 reassured us of the sanity of our cause when the lights of morale were low. Above all, I thank my daughter for her patience with all the meetings and for inspiring this article's luminary themes through her passion for Harry Potter's "defense against the dark arts" and for Mary Poppins's dancing with the leeries. During this period, I also had the fortune to be engaged in a formal course of study in toxicology and environmental epidemiology through a mid-career Mellon "New Directions" Fellowship that gave me the scientific tools to peer through the gaslight. I am grateful for reviewers' comments that challenged me into additional research that led to the discovery of the smoking gun described herein. Any errors, of course, are mine.

\section{References}

Abramson, K. 2014. "Turning up the Lights on Gaslighting." Philosphical Perspectives 28:1-30.

Adams, C., P. Brown, R. Morello-Frosch, J. G. Brody, R. Rudel, A. Zota, S. Dunnagan, J. Tovar, and S. Patton. 2011. "Disentangling the Exposure Experience: The Roles of Community Context and Report-back of Environmental Exposure Data." Journal of Health and Social Behavior 52(2):180-96.

Ahmann, C. 2018. "It's Exhausting to Create an Event Out of Nothing": Slow Violence and the Manipulation of Time. Cultural Anthropology 33(1):142-171.

Allen, J. G., and J. D. Macomber. 2020. Healthy Buildings: How Indoor Spaces Drive Performance and Productivity. Cambridge: Harvard University Press.

Anderson, J. H. 1997. "Reactions to Carpet Emissions: A Case Series." Journal of Nutritional $\mathcal{E}$ Environmental Medicine 7(3):177-186.

Ansell, N. 2009. "Childhood and the Politics of Scale: Descaling Children's Geographies?" 33(2) :190-209.

Babiak, P., and R. D. Hare. 2006. Snakes in Suits: Understanding and Surviving the Psychopaths in Your Office. New York: HarperCollins.

Barton, R., and J.A. Whitehead. 1969. “The Gas-Light Phenomenon.” The Lancet:1258-60.

Beamish, T. 2001. "Environmental Hazard and Institutional Betrayal: Lay-Public Perceptions of Risk in the San Luis Obispo County Oil Spill." Organization and Environment 14:5-33.

Berry, M. A., and D. A. Rondinelli. 2000. "When Business and Government Clash: Environmental Crisis Management in the Carpet Industry." Environmental Quality Management 9(4):1336. 
Berry, M. A. 1990. “A Report on EPA's Indoor Air Research Program 1986-1990.” Deputy Directorship of the Environmental Criteria and Assessment Office. Washington, DC: U.S. Environmental Protection Agency, Office of Research and Development.

-----. 2002. Healthy School Environment and Enhanced Educational Performance: The Case of Charles Young Elementary School, Washington, D.C.: Prepared for the Carpet and Rug Institute, January 12.

-----. 2003. Carpet in the Modern Indoor Environment: Summary of a Science-Based Assessment of Carpet. Conference proceedings of a review panel, July 29-30, at University of North Carolina at Chapel Hill.

----- 2010. Science as it Relates to (OS1). In Fifth Annual Benchmarking Best Practices Symposium. Midway, Utah, July 26, 2006. Accessed July 25, 2020. http://simoninstitute.org/wpcontent/uploads/2011/10/Berry-OS1-Talk.pdf

----. 2011. “Eight Green Cleaning Myths to Consider." Cleanfax Magazine. Accessed July 25, 2020. https: / / www.magicwandcompany.com/green-cleaning-by-dr-michael-berry /

Biehler, D. D., and G. L. Simon. 2010. "The Great Indoors: Research Frontiers on Indoor Environments as Active Political-Ecological Spaces." Progress in Human Geography 35(2):172-192.

Boudia, S., Angela N. H. Creager, Scott Frickel, Emmanuel Henry, Nathalie Jas, Carsten Reinhardt, and Jody A. Roberts. 2018. "Residues: Rethinking Chemical Environments." Engaging Science, Technology, and Society 4:165-78.

Bourdieu, P. 1980. The Logic of Practice. Stanford: Stanford University Press.

Brody, J. G., R. Morello-Frosch, A. Zota, P. Brown, C. Pérez, and R. A. Rudel. 2009. “Linking Exposure Assessment Science with Policy Objectives for Environmental Justice and Breast Cancer Advocacy: The Northern California Household Exposure Study." American Journal of Public Health 99(S3):6000-6012.

Bryson, M. A. 2001. "It's Worth the Risk: Science and Autobiography in Sandra Steingraber's" Living Downstream." Women's Studies Quarterly 29:170-182.

Bjerstedt, R. 2016. “Dear White America: Can We Please Stop Gaslighting our Black Friends and Family?" Medium, November 17.

Carswell, C. 2018. "Household Chemicals Rival Vehicles as Smog Source." Nature. Accessed 19 February 2018. https: / www.nature.com/articles / d41586-018-02132-9

Changing Markets Foundation. 2018. Testing Carpet for Toxics: Chemicals Affecting Human Health and Hindering the Circular Economy. Accessed 19 December 2018. http://www.noburn.org/wp-content/ uploads / FINAL-Testing-Carpet-for-Toxics.pdf

Choy, T., and J. Zee. 2015. “Condition-Suspension." Cultural Anthropology 30(2):210-223.

Conant J. and P. Faden. 2008. A Community Guide to Environmental Health. Berkeley: Hesperian Foundation.

Congress, 107th. 2002. "Green Schools: Environmental Standards for Schools." Senate hearing organized by Committee on Environment and Public Works, October 1. Washington, D.C.: U.S. Government Printing Office.

Davis, A. M., and R. Ernst. 2019. “Racial Gaslighting." Politics, Groups, and Identities 7 (4):761-74. 
Dickson, R. B. 1994. "Regulation of Indoor Air Quality: The Last Frontier of Environmental Regulation." Natural Resources and Environment 9(1):20-22 \& 55.

Douglas, M. 1966. Purity and Danger: An Analysis of the Concepts of Pollution and Taboo. New York: Routledge.

Duehring, C. 1994. The Human Consequences of the Chemical Problem. Chemical Injury Information Network, White Sulphur Springs, MT.

EPA. 1991. Indoor Air Quality and Work Environment Series, EPA Headquarters Buildings. Relating Employee Responses to the Follow-Up Questionnaire with Environmental Measurements of Indoor Air Quality. Research Triangle Park, NC. Volume 3:321 pages.

Fortun, K. 2012. “Ethnography in Late Industrialism." Cultural Anthropology 27(3):446-464.

----- 2014. "From Latour to Late Industrialism." Hau: Journal of Ethnographic Theory 4(1):309-29.

Frickel, S., S. Gibbon, J. Howard, J. Kempner, G. Ottinger, and D. J. Hess. 2010. “Undone Science: Charting Social Movement and Civil Society Challenges to Research Agenda Setting." Science, Technology, \& Human Values 35(4):444-473.

Garnett, E. 2016. "Developing a Feeling for Error: Practices of Monitoring and Modeling Air Pollution Data." Big Data \& Society (July-December):1-12.

Grandia, L. 2020. "Carpet Bombings: A Drama of Chemical Injury in Three Acts." Catalyst: Feminism, Theory, Technoscience 6(1): 1-8.

----. Forthcoming. "Sickly Green: Carpet and the EPA."

Hirzy, J. W., and R. Morison. 1991. "Carpet / 4-Phenylcyclohexene Toxicity: The EPA Headquarters Case." in The Analysis, Communication, and Perception of Risk, edited by Garrick, B. J., and W. C. Gekler, 51-61. New York: Springer (Plenum Press).

Hoover, E. 2017. The River Is In Us: Fighting Toxics in a Mohawk Community. Minneapolis: University of Minnesota Press.

Jackson, D. 2011. Scents of Place: The Dysplacement of a First Nations Community in Canada. American Anthropologist 113 (4):606-18.

Janis, I. L. 1982. Groupthink: Psychological Studies of Policy Decisions and Fiascoes. Second ed. Boston: Wadsworth.

Johnson, A. 2008. Amputated Lives: Coping With Chemical Sensitivity. Brunswick, Me.: Cumberland Press.

Lawson, L. 1993. Staying Well in a Toxic World: Understanding Environmental Illness, Multiple Chemical Sensitivities, Chemical Injuries, Sick Building Syndrome. Chicago: Noble Press, Inc.

Lent, T. 2012. "From The Smokestack To Your Floor, Post Consumer Fly Ash?" October. Accessed 7 October 2018. https:// healthybuilding.net/blog/384-from-the-smokestack-to-yourfloor-post-consumer-fly-ash.

Lewis, A. C. 2018. “The Changing Face of Urban Air Pollution.” Science 359(6377):744-745.

Liboiron, M., M. Tironi, and N. Calvillo. 2018. "Toxic Politics: Acting in a Permanently Polluted World." Social Studies of Science 48 (3):331-49.

McDonald, B. C., J. A. de Gouw, J. B. Gilman, S. H. Jathar, A. Akherati, C. D. Cappa, J. L. Jimenez, J. Lee-Taylor, P. L. Hayes, and S. A. McKeen. 2018. "Volatile Chemical Products 
Emerging as Largest Petrochemical Source of Urban Organic Emissions." Science 359(6377):760-764.

Michaels, D. 2008. Doubt is Their Product. New York: Oxford University Press.

Miller, C. 1997. "Toxicant-Induced Lack of Tolerance: An Emerging Theory of Disease?" Environmental Health Perspectives 105 (2):445-53.

Murphy, M. 2004. "Uncertain Exposures and the Privilege of Imperception: Activist Scientists and Race at the U.S. Environmental Protection Agency." Osiris, 2nd series 19:266-282.

----. 2006. Sick Building Syndrome and the Problem of Uncertainty. Durham, NC: Duke University Press.

Nader, L. 1996. "Controlling Processes-Tracing the Dynamic Components of Power." Current Anthropology 38 (5):97-937.

Nading, A. M. 2020. "Living in a Toxic World." Annual Review of Anthropology 49:209-24.

Nixon, R. 2011. Slow Violence and the Environmentalism of the Poor. Cambridge, Ma.: Harvard University Press.

Norbäck, D. and M. Torgen. 1989. “A Longitudinal Study Relating Carpeting with Sick Building Syndrome." Environment International 15(1-6):129-135.

Perrow, C. 1984. Normal Accidents. New York: Basic Books.

Randolph, T. G. 1962. Human Ecology and Susceptibility to the Chemical Environment. Springfield, Il.: CC Thomas.

Rapp, D. 1997. Is This Your Child's World?: How You Can Fix the Schools and Homes That Are Making Your Children Sick. New York: Bantam Press.

Rather, D with E. Hayes. 1992. New Carpeting May Be the Cause of Illness. CBS evening news. October 29.

Rondinelli, D. A., and M. A. Berry. 1998. "Strategic and Environmental Management in the Corporate Value Chain at Shaw Industries." National Productivity Review (Summer):17-26.

Rudestam, K., P. Brown, C. Zarcadoolas, and C. Mansell. 2004. “Children's Asthma Experience and the Importance of Place." health: An Interdisciplinary Journal for the Social Study of Health, Illness and Medicine 8(4):423-444.

Schulte, B. 2014. Overwhelmed: Work, Love, and Play When No One Has the Time. New York: Sarah Crichton Books.

Shapiro, N. 2014. “Un-knowing Exposure: Toxic Emergency Housing, Strategic Inconclusivity and Governance in the US Gulf South." In Knowledge, Technology, and Law, edited by E. Cloatre and M. Pickersgill. New York: Routledge.

Smith, R. and B. Lourie. 2009. Slow Death by Rubber Duck: The Secret Danger of Everyday Things. Berkeley, Ca.: Counterpoint.

Soviero, M. M. 1992. “Can Your House Make You Sick?” Popular Science, July, 80-2 \& 90-1.

Spear, A. D. 2018. “Gaslighting, Confabulation, and Epistemic Innocence." Topoi 39:229-41.

Stauber, J. C., and S. Rampton. 1995. Toxic Sludge is Good for You: Lies, Damn Lies, and the Public ... Monroe, Me.: Common Courage Press.

Sundell, J. 2004. "On the History of Indoor Air Quality and Health." Indoor Air 14(7):51-58.

Sweet, P. L. 2019. “The Sociology of Gaslighting.” American Sociological Review 84 (5):851-75. 
Szasz, A. 1994. Ecopopulism: Toxic Waste and the Movement for Environmental Justice. Minneapolis: University of Minnesota Press.

Tarr, J. 2004. "Afterword." In Smoke and Mirrors: The Politics and Culture of Air Pollution, edited by E. M. DuPuis. New York: New York University Press. 337-41.

Thompson, B. 2000. Indoor Air Quality: Tools for Schools, IAQ Coordinator's Guide. Washington, DC: U.S. Environmental Protection Agency.

Tironi, M. 2018. "Hypo-interventions: Intimate Activism in Toxic Environments." Social Studies of Science 48 (3):438-55.

Tomory, L. 2012. "The Environmental History of the Early British Gas Industry, 1812-30." Environmental History 17 (1):29-54.

Twilley, N. 2019. "The Hidden Air Pollution in our Homes." New Yorker April 1. Accessed 8 April 2019. https: / / www.newyorker.com/magazine/2019/04/08/the-hidden-air-pollution-inour-homes

Vallette, J., R. Stamm, and T. Lent. 2017. Eliminating Toxics in Carpet: Lessons for the Future of Recycling. Healthy Building Network, October. Accessed 10 December 2017. https: / / healthybuilding.net/ reports / 1-eliminating-toxics-in-carpet-lessons-for-thefuture-of-recycling

Waldman, K. 2016. "From Theater to Therapy to Twitter, the Eerie History of Gaslighting." Slate, April 18. Accessed 6 July 2020. https://slate.com/human-interest/2016/04/the-historyof-gaslighting-from-films-to-psychoanalysis-to-politics.html

Wallace, L. A. 1991. "Comparison of Risks from Outdoor and Indoor Exposure to Toxic Chemicals." Environmental Health Perspectives 95:7-13.

Yeginsu, C. 2018. "How's the Air in London? 'We Should be Worried'." New York Times, April 22. Accessed 23 April 2018. https://nyti.ms/2F810Nw. 